Available online at GSC Online Press Directory

GSC Biological and Pharmaceutical Sciences

e-ISSN: 2581-3250, CODEN (USA): GBPSC2

Journal homepage: https://www.gsconlinepress.com/journals/gscbps

(RESEARCH ARTICLE)

\title{
Inventory of entomofauna associated with crop of okra (Abelmoschus esculentus) and assessment of damage caused by insect pests in Man, west of Côte d'Ivoire
}

\author{
Yao N'guessan ${ }^{1}$, Soro Senan ${ }^{1}$, Obodji Adagba $2,{ }^{*}$ and Ossey Christian Landry ${ }^{3}$ \\ ${ }^{1}$ Laboratory for Improvement of Agricultural Production, UFR-Agroforestry, University of Jean Lorougnon Guédé, Daloa, \\ BP 150 Daloa, Côte d'Ivoire. \\ ${ }^{2}$ Laboratory of Natural Environments and Biodiversity Conservation, UFR-Biosciences, University of Félix Houphouët \\ Boigny, Abidjan-Cocody, 22 BP 582 Abidjan 22, Côte d'Ivoire. \\ ${ }^{3}$ National Center for Agronomic Research, Research Station of Food Crops, Laboratory of Entomology, 01 BP 633 Bouaké \\ 01, Côte d'Ivoire.
}

Publication history: Received on 09 November 2020; revised on 15 November 2020; accepted on 16 November 2020

Article DOI: https://doi.org/10.30574/gscbps.2020.13.2.0365

\begin{abstract}
Okra (Abelmoschus esculentus) is one vegetable crops most cultivated in Côte d'Ivoire. However, the plant is attacked by insects which caused important damage. This study was carried out to inventory entomofauna associated with okra crop and assess the damage caused by the pests. The insects were captured using pliers, sweep net by mowing technique and colored traps. Overall, a total of 61 species belonging to 36 families grouped into 10 orders were identified. During the plant cycle, 11602 insects were collected, including 3663 individuals at before stage flowering (31.57\%); 3757 individuals at the flower bud stage (32.38\%) and 4182 individuals at the flowering-fruiting stage (36.05\%). Analysis of the occurrence frequency showed that Podagrica decolorata was ubiquitous in the crop, causing considerable damage to all organs of the plant. The damage assessment revealed that the defoliators, induced the highest average attack rates at all phenological stages. During the collections, six species (Rhinocoris albopilosus, R. rapax, R. bicolor, Hediocoris fasciatus, Cosmolestes pictus and Coranus $\mathrm{sp}$ ) belonging to the family of Reduviidae were identified as predators of $P$. decolorata. This study therefore made it possible to identify P. decolorata as a major pest of okra and its predators, thus opening up a perspective of biological control as an alternative to chemical control.
\end{abstract}

Keywords: Abelmoschus Esculentus; Entomofauna; Damage; Pests Insect; Côte d'Ivoire.

\section{Introduction}

Okra (Abelmoschus esculentus) belonging to the Malvaceae family is a widely vegetable crop grown in the tropical, subtropical and temperate regions of the world [1], [2]. Annual world production of okra is estimated at six million tonnes [3]. Accordind to Nzikou et al [4], it contains high content of protein, carbohydrates, vitamins A and C, phosphorus, potassium and magnesium. An alcoholic extract of okra leaves is able to eliminate free radical oxygen, improve kidney function and reduce proteinuria [5]. The leaves are sometimes used as a base for poultices, a sudorific emollient or used locally for making fishing lines and game traps. Okra cultivation is highly valued for its edible immature leaves and fruits used in soup and sauce [6]. In Côte d'Ivoire, okra is grown and consumed in all regions. [7], and its local consumption amounts to 90,000 tons/year [8]. However, okra undergo to many damage due to insects and diseases, which seriously limits its cultivation [9]. Of all the vegetables grown in Côte d'Ivoire, okra is the second most ravaged fruit by pests and diseases after tomatoes. [10]. Among the diseases of okra, we are noted virus diseases, fungal

\footnotetext{
${ }^{*}$ Corresponding author: Obodji Adagba

Laboratory of Natural Environments and Biodiversity Conservation, UFR-Biosciences, University of Félix Houphouët Boigny, Abidjan-Cocody, 22 BP 582 Abidjan 22, Côte d'Ivoire.
} 
diseases, bacteriosis, diseases transmitted by nematodes and insects [11]. This study was undertaken within the framework of food security to inventory the entomofauna associated at the crop of okra and to assess the damage caused by insect pests in order to carry out an effective control against insect pests.

\section{Material and methods}

\subsection{Study area}

This study was carried out in Gbintta $\left(7^{\circ} 40 \mathrm{~W}\right.$ and $\left.7^{\circ} 20^{\circ} \mathrm{N}\right)$, a peri-urban area of the city of Man, from June to September 2018 during the rainy season. Man is located in the forest mountainous zone in the west of Côte d'Ivoire. The soil is highly conducive to agriculture, which favorable to many cultures [12]. During study period, average temperatures ranging from 17.5 to $32.9^{\circ} \mathrm{C}$ and total rainfall of $869.3 \mathrm{~mm}$.

\subsection{Experimental design}

Experimental plot with $323 \mathrm{~m}^{2}$ (19 m x $17 \mathrm{~m}$ ) consisted of 3 blocks separated from each other of $2 \mathrm{~m}$. Each elementary plot measured $25 \mathrm{~m}^{2}(5 \mathrm{~m} \times 5 \mathrm{~m})$. The elementary plots $1 \mathrm{~m}$ apart were each consisted of 6 lines spaced from each other of $1 \mathrm{~m}$. Each line is made up of 10 pockets, which makes 60 pockets per elementary plot. The whole experimental plot was made up of total 540 pockets. In study, hiré was the okra cultivar used as plant material.

\subsection{Insect capture and identification}

The insects were captured every three days from the $14^{\text {th }}$ day after sowing using pliers, sweep net by mowing technique and colored traps [13], [14]. The traps consisted of four yellow plastic plates, $17 \mathrm{~cm}$ in diameter and $9 \mathrm{~cm}$ deep, placed on four raks of a trap located at different levels of the ground: $25 \mathrm{~cm} ; 50 \mathrm{~cm} ; 75 \mathrm{~cm}$ and $100 \mathrm{~cm}$. Insects that fly nearby are attracted to and drown in color [15]. A total, 9 yellow traps were placed in the elementary plots in the middle of the 2 central lines. All the insects collected per block and per elementary plot with the sweep net, the pliers and the colored traps were kept in labeled pill boxes containing alcohol at $70^{\circ} \mathrm{C}$ and brought to the laboratory for identification and counting. The identification was carried out using a Leica EZ4 using binocular magnifier, identification keys [16] and books [17], [18], [19], [20]. Ecological parameters such as relative abundance and frequency of occurrence were used to analyze the data.

Relative abundance, expresses the relationship between the number of individuals of a species (Na) considered and the total number of individuals of all species combined (N) [21].

$$
\operatorname{Ar}(\%)=(\mathrm{Na} / \mathrm{N}) \times 100
$$

The frequency of occurrence represents the expressed ratio of the number of collections where the species (Pa) and the total number of collections (P) are found [22].

$\mathrm{C}(\%)=\mathrm{Pa} /(\mathrm{P}) \times 100$

The value of frequency of occurrence allowed to classify the species of insects collected :

- ubiquitous species ( $\mathrm{C}=100 \%)$ observed in all collections;

- constant species $(50 \% \leq \mathrm{C}<100 \%)$ present in more than $50 \%$ of collections

- frequent species $(25 \% \leq \mathrm{C}<50 \%)$ present in $25 \%$ of collections and;

- accessory species present in less than $25 \%$ of collections.

\subsection{Assessment of damage caused by insect pests}

Every three days, damage caused by okra pest insects were observed. To assess the damage, 32 apparently healthy plants were randomly selected from each of the elementary plots in different blocks. At the stage before flowering, all plants with attacked leaves out of the 32 plants were counted. At the flower bud stage, all plants with attacked leaves and flower buds on the 32 plants were counted. At the flowering-fruiting stage, plants with leaves, flower buds, flowers and fruit attacked on the 32 plants were also counted. The rate of attacked plants was calculated using the formula following [23], [24].

$$
\text { Rate of attack }=\frac{\text { Number of plants attacked }}{\text { Number of total plants visited }} \times 100
$$


Average attack rates caused by defoliators, biting sucking and borers were assessed according to okra phenology.

\subsection{Data analysis}

The data processing was carried out using statistica version 7.1 software. Analysis of variance and the Newman-Keuls test at the $5 \%$ threshold to analyze and compare the average attack rates induced by pests (defoliators, biting-sucking and borers) according to phenological stages.

\section{Results}

\subsection{Insects inventoried, relative abundance and frequency of occurrence according to phenological stages}

A total 11,602 insects were caught, it belonging to 61 species grouped into 10 orders and 36 families. The insects collected, by phenological stage, were 3663 individuals at stage before flowering (31.57\%), 3757 individuals at the flower bud stage (32.38\%) and 4182 insects at the flowering-fruiting stage ( $36.05 \%$ ). During stage before flowering, most abundant species was Aphis gossypii with relative abundance of $27.71 \%$. At the bud flower stage, A. gossypii and Podagrica decolorata with respectively abundances of $24.14 \%$ and $24.11 \%$. At the flowering-fruiting stage, P. decolorata was the most abundant species with a rate of $29.27 \%$. The study of the frequency of occurrence has shown an omnipresent species which is $P$. decolorata and 13 constant species, 26 frequent species then 21 accessory species (Table 1).

According action on the okra plants, insects collected were classified into two groups: pests and auxiliaries. The pests consisted of defoliators, biting-sucking and borers.

\subsubsection{Pests}

\section{- Defoliators}

This group of pests included Coleoptera, Lepidoptera and Orthoptera. Only, P. decolorata (Coleoptera) was present at all phenological stages of the plant and attacked several organs (leaves, flower buds, flowers and fruits). Mylabris. variabilis attacked flowers and the remaining species attacked the leaves (Table 2).

\section{- Biting-sucking}

This group of pests consisted of Homoptera, Thysanoptera and Heteroptera. They attacked the leaves and fruits according the phenology of the plant. D. voelkeri was the most dreadful species in this group, and attacked to the fruits (Table 2).

\section{- Borers}

They are mainly composed of the Earias vittella (Lepidoptera) whose larva is a borer of the shoots and fruits of okra. (Table 2).

\subsubsection{Auxiliaries}

Auxiliaries were Heteroptera, Coleoptera and Hymenoptera. The Heteroptera were represented by the family Reduviidae with the species Rhinocoris albopilosus, R. rapax, R. bicolor, Hediocoris fasciatus, Cosmolestes pictus and Coranus sp. All these species are predators of several insects including P. decolorata. Coleoptera represented by Cheilomones sulphurae which is a predatory species of aphids A. gossypii. Certain auxiliaries such as pollinators of the species Apis. mellifera (Hymenoptera) was appeared in large numbers at flowering. 
Table 1 Relative abundance and frequency of occurrence of insect species collected at different phenological stages

\begin{tabular}{|c|c|c|c|c|c|c|c|}
\hline \multirow[b]{3}{*}{ Orders } & \multirow[b]{3}{*}{ Families } & \multirow[b]{3}{*}{ Species } & \multirow{2}{*}{\multicolumn{3}{|c|}{$\begin{array}{c}\text { Relative Abundance } \\
\text { Phenological stages }\end{array}$}} & \multirow{3}{*}{$\begin{array}{l}\text { Frequency occurrence } \\
(\%)\end{array}$} & \multirow{3}{*}{ Class } \\
\hline & & & & & & & \\
\hline & & & $\begin{array}{l}\text { Before } \\
\text { flowering }\end{array}$ & $\begin{array}{l}\text { Bud } \\
\text { flower }\end{array}$ & $\begin{array}{l}\text { Flowering- } \\
\text { fruiting }\end{array}$ & & \\
\hline \multirow{7}{*}{ Coleoptera } & \multirow{2}{*}{ Coccinellidae } & Cheilomones sulphurea Olivier, 1791 & 0.38 & 0.21 & 0.14 & 27.27 & frequent \\
\hline & & Pachnoda cordata Drury, 1773 & 0 & 0 & 0.12 & 13.64 & accessory \\
\hline & Meloidae & Mylabris variabilis Pallas, 1781 & 0 & 0 & 0.53 & 22.73 & accessory \\
\hline & \multirow[t]{3}{*}{ Chrysomelidae } & Ootheca mutabilis Sahlberg, 1829 & 0.27 & 0.21 & 0.26 & 31.82 & frequent \\
\hline & & Podagrica decolorata Duvivier, 1892 & 18.07 & 24.11 & 29.27 & 100 & $\begin{array}{l}\text { ubiquitou } \\
\mathrm{S}\end{array}$ \\
\hline & & Nisotra dilecta Dalman, 1823 & 1.12 & 1.6 & 1.7 & 54.55 & constant \\
\hline & Tenebrionidae & Lagria villosa Fabricius, 1781 & 0.11 & 0.19 & 0.05 & 18.18 & accessory \\
\hline \multirow[t]{9}{*}{ Lepidoptera } & \multirow[t]{8}{*}{ Noctuidae } & Spodoptera littoralis Boisduval, 1833 & 0.11 & 0.24 & 0.41 & 36.36 & frequent \\
\hline & & Anomis flava Fabricius, 1775 & 0.49 & 0.83 & 0.48 & 45.45 & frequent \\
\hline & & Earias vittella Fabricius, 1794 & 0.11 & 0.05 & 0.22 & 36.36 & frequent \\
\hline & & Xanthodes graellsii Feisthamel, 1837 & 0.57 & 0.19 & 0.1 & 31.82 & frequent \\
\hline & & Xanthodes transversa Guenée, 1852 & 0.49 & 0.13 & 0.07 & 18.18 & accessory \\
\hline & & Agrotis ipsilon Hufnagel, 1766 & 0.16 & 0.08 & 0 & 18.18 & accessory \\
\hline & & Helicoverpa armigera Hubner, 1808 & 0.22 & 0.43 & 0.5 & 31.82 & frequent \\
\hline & & Cosmophila flava Fabricius, 1775 & 0,52 & 0.29 & 0.17 & 22.73 & accessory \\
\hline & Pyralidae & Sylepta derogata Fabricius, 1775 & 0.35 & 0.24 & 0.1 & 27.27 & frequent \\
\hline \multirow[t]{3}{*}{ Orthoptera } & \multirow{2}{*}{$\begin{array}{l}\text { Pyrgomorphid } \\
\text { ae }\end{array}$} & Zonocerus variegatus Linné, 1758 & 4.07 & 1.62 & 0.69 & 59.09 & constant \\
\hline & & Pyrgomorpha conica Olivier, 1791 & 0.35 & 0.13 & 0 & 13.64 & accessory \\
\hline & Acrididae & Acrida acuminata Stal, 1873 & 0.44 & 0.27 & 0.14 & 22.73 & accessory \\
\hline
\end{tabular}




\begin{tabular}{|c|c|c|c|c|c|c|c|}
\hline & & Chorthippus brunneus Thunberg, 1815 & 0.22 & 0.03 & 0 & 27.27 & frequent \\
\hline & Tettgonidae & Tettigonia viridissima Linnaeus, 1758 & 0.22 & 0.05 & 0 & 18.18 & accessory \\
\hline & Gryllotapidae & Gryllotalpa gryllotalpa Linnaeus, 1758 & 0.11 & 0.03 & 0 & 18.18 & accessory \\
\hline & Gryllidae & Brachytrupes membranaceus Drury, 1770 & 0.41 & 0.21 & 0.05 & 36.36 & frequent \\
\hline \multirow[t]{10}{*}{ Homoptera } & Aphididae & Aphis gossypii Glover, 1877 & 27.71 & 24.14 & 20.9 & 86.36 & constant \\
\hline & Aleyrdidae & Bemisia tabaci Gennadius, 1889 & 22.19 & 16.42 & 11.17 & 68.18 & constant \\
\hline & \multirow[t]{5}{*}{ Cicadellidae } & Empoasca dolichi Paoli, 1930 & 0.79 & 0.43 & 0.22 & 45.45 & frequent \\
\hline & & Empoasca vitis Gothe, 1875 & 0.49 & 0.21 & 0.1 & 27.27 & frequent \\
\hline & & Jacobiasca sp. & 5.57 & 4.37 & 4.73 & 50 & constant \\
\hline & & $\begin{array}{|llll|}\text { Jacobiasca } & \text { hybrida } & \text { Bergenin } & \text { et } \\
\text { Zano,1922 } & & & \\
\end{array}$ & 1.06 & 0.56 & 0.31 & 40.91 & frequent \\
\hline & & Amrasca sp. & 0.27 & 0.21 & 0.07 & 27.27 & frequent \\
\hline & Diaspididae & Pinnaspis strachani Cooley, 1899 & 0.22 & 0.16 & 0.31 & 22.73 & accessory \\
\hline & Coccidae & Parasaissetia nigra Nietner, 1861 & 0.3 & 0.21 & 0.07 & 13.64 & accessory \\
\hline & Membracidae & Membracis sp. & 0.35 & 0.45 & 0.36 & 40.91 & frequent \\
\hline \multirow{6}{*}{$\begin{array}{l}\text { Hymenopter } \\
\text { a }\end{array}$} & Apidae & Apis mellifera Linnaeus, 1758 & 0.16 & 1.68 & 3.44 & 63.64 & constant \\
\hline & Vespidae & Vespula sp. & 0.46 & 0.24 & 0.33 & 40.91 & frequent \\
\hline & \multirow[t]{3}{*}{ Formicidae } & Lasius niger Linnaeus, 1758 & 0.74 & 0.56 & 0.33 & 50 & constant \\
\hline & & Paltothyreus tarsatus Mayr, 1862 & 3.52 & 4.21 & 2.68 & 72.73 & constant \\
\hline & & Camponatus sp. & 0.19 & 0.13 & 0.02 & 31.82 & frequent \\
\hline & $\begin{array}{l}\text { Ichneumonida } \\
\mathrm{e}\end{array}$ & Lathrestes sp. & 0.44 & 0.35 & 0.45 & 27.27 & frequent \\
\hline \multirow[t]{2}{*}{ Odonates } & Libellulidae & $\begin{array}{l}\text { Trithemis annulata Palisot de Beauvois } \\
1807\end{array}$ & 0.05 & 0.08 & 0 & 9.09 & accessory \\
\hline & $\begin{array}{l}\text { Coenagrionida } \\
\text { e }\end{array}$ & Pseudagrion punctum Rambur, 1842 & 0.03 & 0.11 & 0.05 & 13.64 & accessory \\
\hline
\end{tabular}




\begin{tabular}{|c|c|c|c|c|c|c|c|}
\hline $\begin{array}{l}\text { Thysanopte } \\
\text { ra }\end{array}$ & Thripidae & Thrips tabaci Lindemann, 1889 & 0.49 & 0.21 & 0.14 & 36.36 & frequent \\
\hline Dermaptera & Forficudidae & Forficula auricularia Linnaeus, 1758 & 0.03 & 0.08 & 0 & 9.09 & accessory \\
\hline \multirow[t]{4}{*}{ Diptera } & $\begin{array}{l}\text { Dolichopodida } \\
\text { e }\end{array}$ & Condylostylus sp. & 0.44 & 0.11 & 0.24 & 45.45 & frequent \\
\hline & Asilidae & Tolmerus cingulatus Fabricius, 1781 & 0.33 & 0.29 & 0.38 & 36.36 & frequent \\
\hline & $\begin{array}{l}\text { Scarcophagida } \\
\text { e }\end{array}$ & $\begin{array}{l}\text { Sarcophaga haemorrhoidalis Fallen, } \\
1816\end{array}$ & 0.25 & 0.37 & 0.26 & 36.36 & frequent \\
\hline & Calliphoridae & Calliphora sp. & 0.27 & 0.16 & 0.07 & 27.27 & frequent \\
\hline \multirow[t]{14}{*}{ Heteroptera } & \multirow[t]{3}{*}{ Pentatomidae } & Nezara viridula Linnaeus, 1758 & 0.22 & 0.51 & 0.29 & 59.09 & constant \\
\hline & & Acrosternum acutum Dallas, 1851 & 0.27 & 0.64 & 0.38 & 54.55 & constant \\
\hline & & Aspavia armigera Fabricius, 1775 & 0.16 & 0.11 & 0.22 & 36.36 & frequent \\
\hline & Lygaeidae & Oxycarenus hyalinipennis A. Costa, 1843 & 0 & 0.19 & 0.31 & 27.27 & frequent \\
\hline & \multirow[t]{6}{*}{ Reduviidae } & Coranus griseus Rossi, 1790 & 0.05 & 0.13 & 0 & 13.64 & accessory \\
\hline & & Rhinocoris albopilosus Signoret, 1858 & 0.85 & 2.08 & 2.73 & 63.64 & constant \\
\hline & & Rhinocoris rapax Stal, 1855 & 0.35 & 0.59 & 0.84 & 40.91 & frequent \\
\hline & & Rhinocoris bicolor Fabricius, 1781 & 0.25 & 0.45 & 1.41 & 54.55 & constant \\
\hline & & Hediocoris fasciatus Reuter, 1882 & 0 & 0.05 & 0.02 & 9.09 & accessory \\
\hline & & Cosmolestes pictus Klug, 1830 & 0.03 & 0.11 & 0.22 & 22.73 & accessory \\
\hline & Pyrrhocoridae & Dysdercus voelkeri Schmidt, 1932 & 2.59 & 7.93 & 11.45 & 77.27 & constant \\
\hline & \multirow[t]{2}{*}{ Coreidae } & Anoplocnemis curvipes Fabricius, 1781 & 0 & 0.08 & 0.05 & 9.09 & accessory \\
\hline & & Cletus sp & 0.05 & 0.16 & 0.24 & 18.18 & accessory \\
\hline & Alydidae & Riptortus pedestris Fabricius, 1775 & 0 & 0.11 & 0.22 & 22.73 & accessory \\
\hline 10 Orders & 36 Families & 61 Species & 100 & 100 & 100 & 100 & \\
\hline
\end{tabular}


Table 2 Different groups of okra pests insect

\begin{tabular}{|c|c|c|c|}
\hline Group of insects & Orders & Families & Species \\
\hline \multirow[t]{21}{*}{ Defoliators } & \multirow[t]{6}{*}{ Coleoptera } & \multirow{3}{*}{ Chrysomelidae } & Ootheca mutabilis \\
\hline & & & Podagrica decolorata \\
\hline & & & Nisotra dilecta \\
\hline & & Cetoniidae & Pachnoda cordata \\
\hline & & Meloidae & Mylabris variabilis \\
\hline & & Tenebrionidae & Lagria villosa \\
\hline & \multirow[t]{8}{*}{ Lepidoptera } & \multirow{7}{*}{ Noctuidae } & Spodoptera littoralis \\
\hline & & & Anomis flava \\
\hline & & & Xanthodes graellsii \\
\hline & & & Xanthodes transversa \\
\hline & & & Agrotis ipsilon \\
\hline & & & Helicoverpa armigera \\
\hline & & & Cosmophila flava \\
\hline & & Pyralidae & Sylepta derogata \\
\hline & \multirow[t]{7}{*}{ Orthoptera } & \multirow[t]{2}{*}{ Pyrgomorphidae } & Zonocerus variegatus \\
\hline & & & Pyrgomorpha conica \\
\hline & & \multirow[t]{2}{*}{ Acrididae } & Acrida acuminata \\
\hline & & & Chorthippus brunneus \\
\hline & & Tettigonidae & Tettigonia viridissima \\
\hline & & Gryllotalpidae & Gryllotalpa gryllotalpa \\
\hline & & Gryllidae & Brachytrupes membranaceus \\
\hline \multirow[t]{15}{*}{ Biting-sucking } & \multirow[t]{7}{*}{ Homoptera } & Aphididae & Aphis gossypii \\
\hline & & Aleyrodidae & Bemisia tabaci \\
\hline & & \multirow[t]{5}{*}{ Cicadellidae } & Empoasca dolichi \\
\hline & & & Empoasca vitis \\
\hline & & & Jacobiasca sp. \\
\hline & & & Jacobiasca hybrida \\
\hline & & & Amrasca sp. \\
\hline & Thysanoptera & Thripidae & Thrips tabaci \\
\hline & \multirow[t]{7}{*}{ Heteroptera } & \multirow[t]{3}{*}{ Pentatomidae } & Nezara viridula \\
\hline & & & acrosternum acutum \\
\hline & & & Aspavia armigera \\
\hline & & Lygaeidae & Oxycarenus hyalinipennis \\
\hline & & Pyrrhocoridae & Dysdercus voelkeri \\
\hline & & \multirow[t]{2}{*}{ Coreidae } & Anoplocnemis curvipes \\
\hline & & & Cletus spp \\
\hline Borers & Lepidoptera & Noctuidae & Earias vittella \\
\hline
\end{tabular}




\subsection{Assessment of damage caused by insect pests according to the phenological stages of okra}

\subsubsection{Stage before flowering}

Defoliators induced an average attack rate of $27.26 \pm 3.26 \%$ and biting-sucking induced an average attack rate of 21.01 $\pm 1.59 \%$. Statistical analysis showed insignificant differences between the average attack rates of the two groups of insects ( $\mathrm{DF}=1 ; \mathrm{F}=2.96$ and $\mathrm{P}>0.094$ ) (Figure 1A).
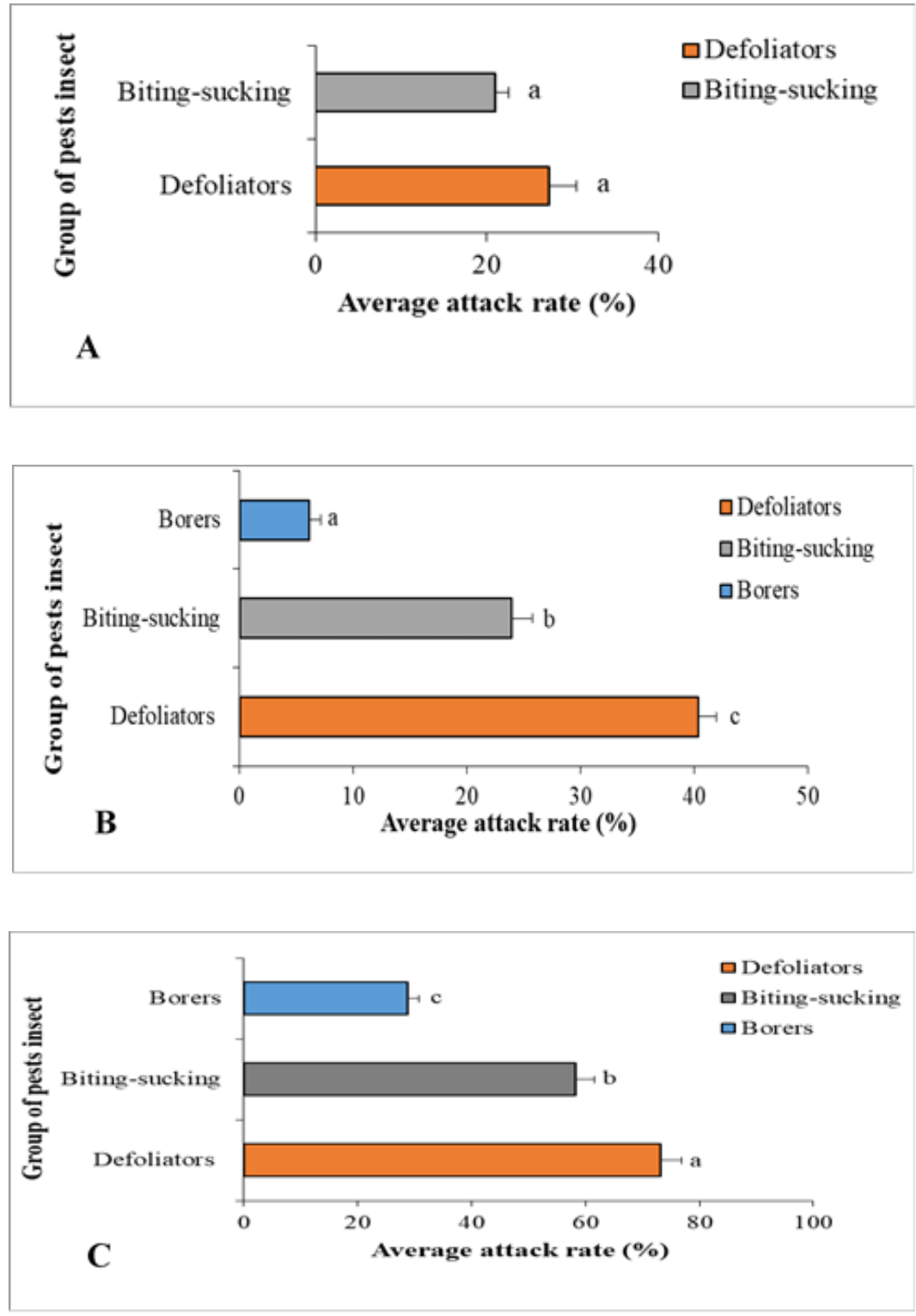

Figure 1 Average attack rate induced by insect pests at different phenological stages of okra. A: Stage before flowering; B: Flower bud stage; C: Flowering-fruiting stage

\subsubsection{Flower bud stage}

At the flower bud stage, the average attack rate caused by defoliators was $40.33 \pm 1.63 \%$ and biting-sucking were induced average attack rate of $23.96 \pm 1.83 \%$. The borers induced an average attack rate of $6.10 \pm 1.07 \%$. Statistical analysis showed significant differences between the average attack rates of the three groups of insects (DF $=2 ; \mathrm{F}=$ 122.99; $\mathrm{P}<0.01$ ) (Figure1B). 


\subsubsection{Flowering fruiting stage}

The average attack rate induced by defoliators was high at $73.24 \pm 3.54 \%$. Biting-sucking, caused an average attack rate of $58.25 \pm 3.22 \%$ and borers caused an average attack rate of $28.77 \pm 1.94 \%$. Statistical analysis showed significant differences between the average attack rates of the three groups of insects ( $D F=2 ; \mathrm{F}=57.62 ; \mathrm{P}<0.01$ ) (Figure $1 \mathrm{C}$ ).

\section{Discussion}

A total, 61 species belonging to 36 families and grouped into 10 orders were identified during study. Among species inventoried P. decolorata, A. gossypii, B. tabaci, D. voelkeri, S. derogata, M. variabilis and Jacobiasca sp were identified previously in Côte d'Ivoire by authors during their work as main insects okra pest [25], [26]. Same species have also been identified in Pakistan and India as okra pests [27], [28].

Concerning auxiliaries insect, $A$. mellifera was identified as a pollinator of okra flowers our results are similar with those Angbanyere and Matthew [29] in Burkina Faso who showed that A. mellifera is the major pollinator of $A$. esculentus. Other auxiliaries were identified as predators. It is C.sulphurea which is aphid predator. Our results are similar to those of Adja et al., [26] and Mrosso et al., [30] who during their work showed that C. sulphurea is an excellent predator of aphids. The predator group was also represented by the family Reduviidae, five species of this family were identified as predators of $P$. decolorata. These are R. albopilosus, $R$. bicolor, R. rapax, H. fasciatus, C. pictus, and Coranus sp. Our results are close to those of Kwadjo et al., [31] who identified $R$. albopilosus during their work as predators of $D$. voelkeri and $P$. decolorata. In their work on cowpea entomofauna, Ossey et al., [32] showed that R. albopilosus, R. bicolor, R. rapax are predatory species of Ootheca mutabilis. Other work by Tendeng et al., [33] on updating the entomofauna of vegetable crops in Casamance (Senegal) identified C. pictus as a predatory species of $P$. decolorata. As for Coranus sp. it has been listed by Ambrose and Kumar [34] as predator of E. vitella, S. derogata and H. armigera.The relative abundance of $P$. decolorata, B. tabaci, D. voelkeri, M. variabilis A. mellifera and A. gossypii showed that the presence of these insects on the plot was a according phenology of okra. Thus, the species A. mellifera and $M$. variabilis which were not abundant on the experimental plot at stage before flowering were abundant at flowering. This high abundance at flowering is due to the fact that these insects were attracted large numbers to flowers. The frequency of occurrence has shown that $P$. decolorata was ubiquitous at all phenological stages of okra. This ubiquity could be explained by the fact that this pest attacked several organs plant (leaves, flower buds, flowers and fruits). These results are similar to those of Ossey et al., [32] who reported during their work that 0 . mutabilis was present at all phenological stages and attacked several organs of the plant. The pest insects were classified into three groups according to their mode of action on the host plant. Thus, defoliators, biting-sucking and borers were distinguished. The attack rate induced by defoliators at stage before flowering was higher than that caused by biting-sucking. Our results corroborate those of Fomekong et al., [35] and Ossey et al., [32] who showed during their work that at this stage the leaves are tender and contain water, this is would justify their attraction to defoliators. At the bud flower stage, borers were collected, their presence at this stage of development is due to the appearance of flower buds. At the flowering-fruiting stage, average attack rate of defoliators was higher than that observed in previous stages, this would be due to the fact that the nutritive resources were important at this stage,several insects were therefore attracted. Our study also showed that the larvae of $E$. vitella were drilled shoot, flower buds and fruits of okra. These results are similar to those of Sharma et al., [36], who revealed during their study that E. vitella is an okra organ borer. All okra organs were attacked by insect pests, but the highest average attack rate induced by defoliators would be explain by important defoliation of the okra leaves by Coleoptera. According to Soro et al., [14] P. decolorata, was recognized as the voracious pest of okra, which mainly attacks the leaves. Works of Tano et al., [37] also showed that P. decolorata was caused considerable defoliation of okra leaves at all phenological stages of plant.

\section{Conclusion}

This study revealed diversity of insects associated with okra crop. These insects were composed of pests and auxiliaries. The pests were defoliators, biting-sucking and borers. The auxiliaries consisted of predators and pollinators. Among the insect pests, $P$. decolorata was major pest of okra pest because, it attacked all organs and induced high average attack rate at all phenological stages. Among the auxiliaries, six species belonging to Reduviidae family were identified as formidable predators of $P$. decolorata. The leaves were the most attacked organs, several perforations on the leaves were occasioned by pests reducing photosynthetic surface. This study therefore revealed $P$. decolorata as major pest of okra and its predators, thus opening up a prospective of biological control as an alternative to chemical control in order to improve the production of okra in Côte d'Ivoire. 


\section{Compliance with ethical standards}

\section{Acknowledgments}

The authors thank all who were contributed to the success of this study.

\section{Disclosure of conflict of interest}

The authors declare that there is no conflict of interest.

\section{References}

[1] Lamont JRW J. Okra-A versatile vegetable crop. Horticultural Technology, 1999; 9 (2):179-184.

[2] Saifullah M and Rabbani MG. Evaluation and characterization of okra (Abelmoscus esculentus L. Moench.) genotypes. SAARC Journal of Agriculture, 2009; 7:92-99.

[3] Sathish KD, Eswar TD, Praveen KA, Ashok KK, Bramha SRD and Ramarao N. A review on: Abelmoschus esculentus (Okra). International Research Journal of Pharmaceutical and Applied Sciences, 2013; 3 (4):129-132.

[4] Nzikou JM, Mvoula T, Matouba E, Ouamba JM, Kapseu C, Parmentier M, Oyen LPN and Jemmens RHM. A study on gumbo seed grown in Congo Brazzaville for its food and industrial applications. African Journal of Biotechnology, 2006; 5 (24):2469-2475.

[5] Siemonsma JS and Kouamé C. Vegetable. Plant Resource of Tropical Africa. ; 28p.

[6] Khomsug P, Thongjaroenbuangam W, Pakdeenarong N, Suttajit M. and Chantiratikul P. Antioxidative activities and phenolic content of extracts from Okra (Abelmoschus esculentus L.). Research Journal of Biological Sciences, 2010; 5: 310-313.

[7] Fondio L.et Djidji A. H., 2007. Bien cultiver le gombo en Côte d'Ivoire, Centre National de Recherche Agronomique (CNRA): 4p. 2010

[8] FAO. 2009. Rapport National sur l'état des ressources phytogénétiques pour l'alimentation et l'agriculture : 65p.

[9] N'guessan KP. Contribution à l'étude de l'enroulement du gombo (okra leaf curl virus). Diplôme d'Etude Approfondie d'écologie tropicale ès-sciences et techniques. Université de Cocody (Côte d'Ivoire), 1987; 42p.

[10] Déclert C. Manuel de phytopathologie maraîchère tropicale. In cultures de Côte d'Ivoire. Institut Français de Recherche Scientifique pout le Développement en Coopération. Collections Didactiques. Editions de l'ORSTOM, 1990; Paris: 98-102: et 123-133.

[11] Fondio LS, Djidji AH and Zohouri GP. . Diagnostic prophylactique du secteur maraîcher de la région d'Abidjan (Délégation Régionale Sud de l'ANADER) : contraintes et ébauches de solutions. Rapport d'étude, CNRA, Bouaké, Côte d'Ivoire. 2001 ; 28p.

[12] Boyossoro HK, Koffi FK, Bachir MS, Biémi J and Traoré I. Insécurité climatique et géorisques en Côte d'Ivoire : étude du risque d'érosion hydrique des sols dans la région semi-montagneuse de Man (Ouest de la Côte d'Ivoire), Science et changements planétaires / Sécheresse. 2007; 18 (1):29-37

[13] Obodji A, Aboua LRN, Tano DKC and Seri-Kouassi BPh. Inventory of entomofauna associated with African eggplant (Solanum aethiopicum ) according to the phenological stages and assessment of damages caused by insect pests. Journal of Advanced Studies in Agricultural, Biological and Environmental Sciences. 2016; 3(2):12-21.

[14] Soro S, Yéboué NL, Tra Bi CS, Zadou DA and Koné I. Dynamics of the flea beetle Podagrica decolorata Duvivier, 1892 (Insecta : Chrysomelidae) on okra cops implications for conservation of the Tanoe-Ehy Swamp Forests (Southeastern Ivoiry Coast). Journal of Animal \& Plant sciences, 2016; 30:4758-4766.

[15] Franck A. Capture conditionnement expéditions mise en collection des insectes et acariens en vue de leur identification. CIRAD Réunion, 2008; 53p.

[16] Delvare G and Aberlenc HP. Les insectes d'Afrique et d'Amérique tropicale. Clés pour la reconnaissance des familles. CIRAD. Laboratoire de Faunistique. Acridologie Opérationnelle. Montpellier Cedex, France, 1989; 299 p.

[17] Roth M. Initiation à la morphologie, la systématique et la biologie des insectes, Office de la Recherche Scientifique et Technique Outre-mer (ORSTOM), 1974; 213 p. 
[18] Appert J and Deuse J. Insectes nuisibles aux cultures vivrières et maraîchères, Ed. maisonneuve et Larose, Paris, 1988; $267 \mathrm{p}$.

[19] Scholtz CH and Holm E. Insects of Southern Africa, 1996; 502 p.

[20] Poutouli W, Silvie P and Aberlenc HP. Hétéroptéres phytophages et prédateurs d'Afrique de l'Ouest. Edition Quae, Paris (France), CTA, 2011; 79p.

[21] Zaime A and Gautier JY. Comparaison des régimes alimentaires de trois espèces sympatriques de Gerbillidae en milieu saharien au Maroc. Revue d'Ecologie, Terre et vie. 1989 ; 44 (3):263-278.

[22] Dajoz R. Précis d'écologie. 7ème édition, Paris : Dumond, 2000; 615p.

[23] Dupriez H, Silas N and Colin J. Champs et jardins sains, lutte intégrée contre les maladies et les ravageurs des cultures. Carnets écologiques d'Afrique. Terre et Vie, Bruxelles, Belgique, 2001; 238 p.

[24] Murúa G, Molina-Ochoa J and Coviella C. Population dynamics of the fall armyworm, Spodoptera frugiperda (Lepidoptera: Noctuidae) and its parasitoids in northwestern Argentina. Florida Entomologist. 2006 ; 89 (2):175182.

[25] Gnago JA, Danho M, Agneroh AT, Fofana IK and Kohou AG Efficacité des extraits de neem (Azadirachta indica) et de papayer (Carica papaya) dans la lutte contre les insectes ravageurs du gombo (Abelmoschus esculentus) et du chou (Brassica oleracea) en Côte d'Ivoire. International Journal Biological Chemical Sciences. 2010; 4 (4):953-966.

[26] Adja NA, Nandjui J, Sadia GH, Adingra T, Akamou F and Danho M. Are bioinsecticides able to effectively substitute chemicals in the control of insect pests of okra (Abelmoschus esculentus L. Moench) in Côte d'Ivoire? Journal of applied Biosciences. 2019; 142:14435-14447

[27] Bhutto ZA, Magsi FH, Soomro AA, Chandio MA, Channa NA, Lashari SH, Mangi S and Junejo AA. Integrated pest management of okra insect pests. International Journal of Fauna and Biological Studies. 2017; 4 (3):39-42.

[28] Bhatt B, Joshi S and Karnatak AK. Biodiversity of insect pests and their predators on okra agroecosystem. Journal of Pharmacognosy and Phytochemistry. 2018; 7(4):84-86.

[29] Angbanyere and Matthew A.The effect of pollinators and pollination on fruit set and fruit yields of okra (Abelmoschus esculentus L. Moench) in the forest region of Ghana. Thesis of doctoral, Kwamé Nkrumah University of Science and Technology College of Science. 2012; 103 p.

[30] Mrosso F, MWatawala M and Rwegasira G. Functional responses of Cheilomenes propinga, C. lunata and C. sulphurea (Coleoptera : Coccinallidae) to predation on Aphis gossypii (Homoptera : Aphididae) in Eastern Tanzania. Journal of Entomology. 2013; 10 (2):76-85.

[31] Kwadjo KE, Doumbia M, Ishikawa T, Tano Y, and Haubruge E. Morphometrical changes and description of eggs of Rhynocoris albopilosus Signoret (Heteroptera: Reduviidae) during their development. Faunistic Entomology, 2008; 61 (4):151-155.

[32] Ossey CL, Aboua LRN, Obodji A and Tano DKC. Entomofauna associated with cowpea Vigna unguiculata (L.) Walp., assessment damages caused by insect pests and predators of Ootheca mutabilis Sahlberg (Coleoptera: Chrysomelidae) in south of Côte d'Ivoire. IJRDO-Journal of Applied Science. 2017; 4(3):2455-6653.

[33] Tendeng E, Labou B, Djiba S and Diarra K. Actualisation de l'entomofaune des cultures maraîchères en Basse Casamance (Sénégal) International Journal of Biological and Chemical Sciences. 2017; 11(3):1021-1028.

[34] Ambrose DPand Kumar AG. Reduviid predators. In: Omkar (Ed.), Ecofriendly Pest Management for Food Secutity. Academic Press, 2016; pp. 217-257.

[35] Fomekong A, Messi J, Kekeunou S, Tchuenguem-Fohouo FN and Tamesse JL. Entomofauna of Cucumeropsis manii, its impact on plant yield and some aspects of the biology of Dacus bivittatus (Diptera: Tephritidae). African of Journal Agriculture Research. 2008; 3 (5): 363-370.

[36] Sharma RP, Swaminathan and Bhati KK. Seasonal incidence of fruit and shoot borer of okra along with climatic factors in Udaipur region of India. Asian Journal of Agricultural Research, 2010; 4(4):232-236.

[37] Tano DKC, Tra Bi CS, Kouassi KA, Ossey CL and Soro S. Incidences des attaques de Podagrica decolorata 1892 (Coleoptera : Chrysomelidea) sur la culture du gombo et contrôle de ces adultes au moyen du biopesticide NECO 50 EC (Daloa, Côte d'Ivoire). Journal of Applied Biosciences. 2019; 143:14692-14700. 